\title{
Waking up to the dawn of a new era: Reconceptualization of curriculum post Covid-19
}

\author{
Sümer Aktan ${ }^{1}$ D
}

Accepted: 28 November 2020 / Published online: 20 January 2021

(C) UNESCO IBE 2021

\begin{abstract}
Covid-19, the most severe global pandemic since the Spanish flu that followed World War I, threatens nearly every country, from global powers to developing nations. This threat presents a concurrent challenge for educational systems. With schools closed during the pandemic, students and teachers have had to stay at home worldwide. This shift has required us to move beyond conventional ideas regarding education. From kindergarten to higher education, schools offered web-based and online classes, both synchronous and asynchronous. However, while technology emerged as a savior, it is not possible to achieve thorough learning only by listening or watching content. Instead of championing technologies in which pedagogy is irrelevant, schools must invest in helping students become lifelong learners, enrich their learning processes, and focus on critical self-reflection, problem-solving skills, imagination, ideas, and projects involving social problems. A significant attempt to redefine the concepts that we have traditionally used must be made. The aim of this article is to develop new suggestions on how curriculum as the essence and core of all educational systems can be reconceptualized for the post-Covid-19 era.
\end{abstract}

Keywords Curriculum $\cdot$ Covid-19 $\cdot$ Ecology $\cdot$ Crisis $\cdot$ Education systems $\cdot$ Online learning $\cdot$ Pandemic $\cdot$ Technology

Karl Marx and Friedrich Engels open The Communist Manifesto with this sentence: "A spectre is haunting Europe-the spectre of communism" (Marx and Engels 1910, p. 11). When the manifesto was first published in 1848, all the powers of Europe were preoccupied with the danger this spectre posed for them. Marx and Engels had given voice to the call of a social class to eliminate poverty and oppression. A hundred and seventytwo years later, a new threat has caught humanity unprepared. However, today's threat

Sümer Aktan

saktanus@gmail.com

1 Department of Curriculum and Instruction, Necatibey Faculty of Education, Balıkesir University, Soma Cad, Dinkciler Mah, Altieylül, Balikesir, Turkey 
destroys humanity with no regard for social class. Not only the powers of Europe but also the world's "superpowers" confess their desperation before it. As the world wakes up to the reality of Covid-19, Europe, the Americas, Africa, and Asia are suffering at the hands of an extraordinary crisis.

Although the global pandemic will eventually come to an end, it will leave traces, having started a fire of change on an unprecedented scale. Simon Mair (2020), writing about this change, is correct to ask, could the huge shifts in our ways of life being introduced as part of the fight against Covid-19 pave the way for a more humane economy? James Meadway (2020) states that the coronavirus caused a crisis of capitalism that has never been this deep and that fundamental changes are awaiting the global capitalist system. The pandemic, notes Alex Callinicos (2020), enables us to better see the sickness of capitalism.

The situation of the poor once again stands out (OECD 2020a). That condition deteriorates day by day for people with no social security (Sumner, Hoy, and Ortiz-Juarez 2020). In fact, the pandemic has provoked questioning of social welfare and healthcare structures in developed countries. While economically advantaged countries find makeshift solutions to social problems through drastic measures, the condition of economically disadvantaged countries, where more people have no choice but to go out to work, has worsened. As Ulrich Beck states (1992), society in the 21st century is turning into a "risk society", in which the risk is so great that all are vulnerable to the threat it brings.

While the global capitalist economy is fighting against the crisis in which it finds itself, another vast issue has emerged in education systems and on a scale unimaginable even for the world's most developed education countries. UNESCO (2020a) stated that as of April 2020 , schools were closed due to this outbreak in 188 countries and that 1,576,021,818 students globally are continuing their education away from school. Countries have set their focus on maintaining learning and preventing students from falling behind by means of radio and television streaming, online courses, and virtual classes (UNESCO 2020b). However, in most areas, infrastructure, access to the internet, and economic deprivation make it difficult to provide distance education (Woolley et al. 2020; Taylor 2020). Other critical issues that now preoccupy policymakers are how to evaluate courses taken via distance education, how to manage schools if and when they are re-opened, the isolation of students at home, the psychological load on families, and the pressure on teachers who must work under the difficult conditions of remote learning (United Nations 2020; WHO 2020).

Three hundred thirty teachers from 98 countries responded to the question, "What areas of intervention should be prioritized during the pandemic process?" and answered as follows: continuation of learning processes, $83.93 \%$; professional support to teachers, $77.87 \%$; support for the wellbeing of teachers, 77.57\% (OECD 2020b, pp. 10-15).

In addition, a deeper concern of educational systems has once more gained currency: In a period that has so fundamentally reshaped our lives and habits, how will we prepare children for the difficulties ahead? Human history shows that significant turning points have contributed to the reconstruction of social structures and reconceptualization of education. The pandemic period-its endpoint still unknown — is such a turning point. The world is being forced to build a new human typology with new values. But it is not just because Covid-19 has shaken the foundations of the world's economic systems, led to hundreds of thousands of deaths, and a questioning by humanity its own existence but also because of concurrent crises, including immigration, climate change, hunger, consumerism, and antidemocratic movements that have contributed to increasing violence, racism, and othering.

At another historical milestone, Herbert Spencer (1895) asked the question, What knowledge is of most worth? What led him to pose this question was the technological, industrial, and economic development of his era and the world getting smaller as a result 
(Lawton 2009). Now, more than a century later, the period of the pandemic has made the world even smaller and also demands technological and economic shifts in societies struggling to survive. When considering the main task of curriculum against the threat of existing and newly emerging issues, Spencer's question is still valid: What knowledge is of most worth?

It should be emphasized that the crisis of Covid-19 surpasses in its damaging effects even the Great Depression of the 1930s (Martin 2020). If we carefully investigate the postGreat-Depression trauma of the United States, which as an advanced capitalist country was perhaps most affected, and explore proposals to address the problems that emerged in that era, we may also find remedies for the Covid-19 pandemic and the issues that have arisen with it.

Another important reason to study the post-Great-Depression period in the United States is that the work and efforts of academicians in three US universities of that period (Ohio State University, Columbia University Teachers College, and University of Chicago) played a crucial role in the emergence and cultivation of curriculum as a scientific field of study. By examining curriculum issues in this historical context, we are able to illuminate curricular problems in the current period of crisis.

The fundamental problem of education in the post-Covid-19 era will be, What knowledge is of most worth when constructing a new social and global awareness through curriculum? To this end, I will address George S. Counts' (1932) proposed solution to the socio-economic crisis that emerged from the Great Depression. Next, drawing upon relations between Franklin Bobbitt's ideas of change and transformation in The Curriculum (1918), I will examine the driving forces that induced change in curriculum in that earlier era of crisis. Thirdly, I will examine the relationship between human beings, nature, and education through the lens of the ecological crisis, in which eco-schools are seen as spaces of curricular practice that internalize nature as the main source of life. The last section consists of my remarks on curricular imagery post Covid-19 that continually seeks to answer: What knowledge is of most worth?

\section{Curriculum for crisis times: Remembering George S. Counts}

The economic crisis of the Great Depression led to deep social breakdown in American society in a very short time (Bernstein 1987; Elder 1999). This breakdown turned into a social crisis that occupied the society as a whole a result of its lack of readiness to handle and organize processes of change in the aftermath of rapid scientific and technological development. To combat this social crisis, the American thinker George S. Counts (1932) advocated changes to the education system that may help us untangle issues presented by the Covid-19 pandemic. Counts is a focus of this study because of his early emphasis on educational inequality and a comprehensive framework for reconstructing a society and social structure in crisis by means of education. He saw the construction of a new economic structure as a necessity to combat the inequalities of capitalism and redesigned school as the key to this change process.

Educational systems, he argued, do not prepare individuals for social and cultural change, either mentally or behaviorally (Gutek 1984; Lagemann 1992). Only individuals with problem-solving skills, who can easily adapt to change, can construct a road to social development and progress. Counts saw school as an institution at the center of social development and sought to create a new curricular and instructional understanding based on 
participatory democracy. The curriculum he envisioned had two main features. First was the development of democratic habits, tendencies, and interests; second was the acquisition of knowledge and comprehension as preparation for intellectual participation in a democratic society. Such schools would (a) respect the equality of all people, (b) develop the talents and tendencies of the individual, (c) discuss, criticize, and decide on issues using a democratic process, and (d) give importance to personality and character development through a holistic and scientific ethos (Gutek 1988).

\section{Driving forces of a new curriculum}

Historically, educational imagery and curricular thought have shifted when societies are forced to change socially or economically. The conservative curricular thought of the Yale Report of 1828, unable to resist capitalism or technological change, ceded its place as a change agent to the social efficiency movement. J. Franklin Bobbitt (1918), who comprehended this change process very well, was one of the first to notice the key role curriculum would play in it. Bobbit articulated a systematic perspective on why, for what, purpose, and how curriculum must change, a view that became a source of inspiration for the social efficiency movement. He remains a significant and inspirational figure among those forces driving curriculum change in the Covid-19 era.

When Bobbitt came up with the first draft of his curriculum theory (1918), the world had been witnessing the rise of capitalism alongside the development of technology. There were Henry Ford's mass production system, Taylor's scientific method (1913), and in alignment with Thorndike's (1918) and Judd's (1918) behaviorist psychology, a strong belief that people would reach goals of social efficiency as a result of individuals' effectively taking their place in and contributing to the capitalist production process and capitalist social structure (Callahan 1964; Cremin 1988; Kliebard 2004)—a more systematic version of the program envisioned by Bobbitt.

Tyler's (1949) rationale was nothing other than a more systematic and applicable version of perspectives introduced by Bobbitt, Charters, and Snedden. Tyler's perspective was highly compatible with their focus on mass schooling, the increase in urban populations, and the curricular needs of a developing social structure (Lau 2001)—so much so that Jackson (1992, p. 24) remarked, "If any single volume deserves to be called the bible of curriculum making, it is certainly Ralph Tyler's Basic Principles of Curriculum and Instruction". Tyler's rationale, which engulfed schools in a techno-scientific conceptualist swirl, was a remarkable reflection of the spirit of its time.

Technological and social factors have always affected the structure of curricula. In The Curriculum (1918), Bobbitt stated the necessity of changing the curricular perspective of the era in parallel with the era's mind-blowing technological and social developments:

Since the opening of the twentieth century, the evolution of our social order has been proceeding with great and ever-accelerating rapidity. Simple conditions have been growing complex. Small institutions have been growing large. Increased specialization has been multiplying human interdependencies and the consequent need of coordinating effort. Democracy is increasing within the Nation; and growing throughout the world. All classes are aspiring to a full human opportunity. Never before have civilization and humanization advanced so swiftly (Bobbitt 1918, p. III).

Impulses similar to Bobbitt's desire for fundamental change in the structure of curriculum have reemerged periodically throughout history. The days following the launch of Sputnik 
in 1957 witnessed the sudden awakening of the American public to the fact that American schools had fallen far behind Soviet educational systems, leading to a fundamental change in American school programs (Kliebard 2004; Steeves, Bernhardt, and Burns 2009; Urban 2010). In terms of their educational messages, the statements in A Nation at Risk (National Commission on Excellence in Education 1983, p. 114) resemble those of Bobbitt's statement of 1918:

The world is indeed one global village. We live among determined, well-educated, and strongly motivated competitors. Knowledge, learning, information, and skilled intelligence are the new raw materials of international commerce...Learning is the indispensable investment required for success in the "information age" we are entering.

Similar statements can be found in the Goals 2000: Educate America Act (1994). References in that act to compatibility with competition, ability to use technology, and global economic leadership emphasize the same message as the texts of 1983 and 1918. The common ground of these three important documents published in that 74-year-period is that in a world where change and transformation are experienced globally and locally, education's most significant objective should be to provide students with intellectual competency so that they can rapidly adapt to change, solve problems that arise in relation to change, and understand the society and world in which they live.

While the prevailing paradigm and driving force of the past was constructed with the goal of not falling behind economically and developing constantly, the foundation and driving force for a new curriculum in our own time, as I will argue in the following section, is ecology.

\section{Ecology: The main problem for humanity}

Especially since the beginning of the past century, the foundational incentive for change and transformation in the curricula has been the need to bringing up new generations qualified to serve the capitalist economy. In other words, the concept of human capital became fundamental to the change in curriculum. The pandemic period has given us an opportunity to remember the earth, the environment, and other living beings we share the earth with. In discussing Covid-19 and its effects, humanity's relationship with nature has become a constant theme. Baker (2019) points out that technology and the distorted relationship of humans with nature stand out among the most significant issues we are facing.

Humanity walked away from high ethical values and spoiled the balance and harmony of the world. This was a natural result of a strictly self-centered economic understanding based on consumption and waste and aimed solely at economic rent and profit. It has devastated nature to such a degree for the sake of its ambitions that this era of exploitation is called the Anthropocene, the era of geologic change caused by human activity. The most negative effects of the Anthropocene are the harms done to biodiversity on earth, climate change, and increasing carbon dioxide emissions. Other characteristics of the Anthropocene include turning oceans into plastic waste dumps, irregular and unplanned urbanization, destruction of forests for more income, and the extinction of animals who have lost habitat (Leinfelder 2013; Steffen et al. 2011; Zalasiewicz et al. 2010; Wals and Corcoran 2012). The future of the world is threatened by the problems of the Anthropocene, and there is an urgent need to create awareness in children about these threats. The World 
Economic Forum (2017) states that half the problems facing the world's youth between the ages of 18-35 are environmental issues.

It is therefore not surprising that today's youth are highly sensitive to the devastating effects of the Anthropocene. Youth show higher levels of solidarity when it comes to the issues of climate change and the environment (Baker 2019). Their objection to the status quo and leadership of change and transformation have been key to several cultural and political movements (Arnold et al. 2009; Blythe and Harre 2012; Hickman et al. 2016). The participation of 1.4 million students worldwide in the protest led by Greta Thunberg is a concrete example of this solidarity (Carrington 2019).

When we educate children to comprehend the risks that accompany environmental disasters, who realize the necessity of a clean environment, they can become part of an environmentally conscious global class capable of shaping the future. When they become adults, they will vote for the protection of the environment and natural resources, and even before adulthood may affect the voting preferences of their parents. Developing in children and youth an awareness of and sensitivity to environmental disasters and empowering them to develop praxis for environmental issues are possible only if they internalize the belief that the world's future depends on sustainable development, in which human beings and nature are regarded holistically.

Ecological schools, or eco-schools, in which students internalize the idea of nature as the main source of life, are important examples of this internalization (Pauw and Petegem 2013; Mogensen and Mayer 2005). The main goal of eco-schools is to provide students with experiences that lead them to comprehend the significance of eco-systems and sustainable living for humans and other living beings (Eco-Schools 2020a; Gadotti 2010; Scott 2009). A different kind of pedagogy is needed to reach this goal, one that involves a transition from a passive, listening-based school structure to a production-based school structure and active practice. This "to know is to do" approach should be the guiding principle of the school's pedagogic practices. The school has to be organized in such a way that students experience freedom, equity, respect for differences, and democratic consciousness.

Eco-schools are based on internalization of the idea that our futures are entwined with one other and with those of the other living beings that share our environment. For this reason, the curriculum of eco-schools is constructed on ten themes. These themes are biodiversity, energy, food and the environment, global citizenship, health and wellbeing, school grounds, transport, waste minimization, water, and litter (trash) (Eco-Schools 2020b). Instruction in these themes requires an interdisciplinary approach: Students gain an understanding of the social dimensions of ecological change through the instructional bridge between natural sciences and sociology, and they develop both local and global awareness by analyzing environmental issues (Bajd and Leščanec 2011; Krnel and Naglič 2009).

The path to developing conscious praxis and conscious attitudes toward environmental problems that threaten our future most is to shift our schools closer to the human/nature axis and even, in the post-Covid-19 era, to transform them into ecoschools. A good starting point is to let our students comprehend the human as part of the nature they share with other living beings and to understand the importance of water, soil, and air for the future of humanity. When students discover the importance of nature and biodiversity through a participatory, inquiry-based, and democratic atmosphere, it can lead to a deeper comprehension of compassion, affection, and goodness. If we adopt a new perspective toward our countless critical problems and wish to 
construct our schools and pedagogical thought in response to these new living conditions, then we need a new curricular perspective, as well.

\section{The new perspective on curriculum}

Ensuring the connection of curriculum with life holds a highly significant place in the Deweyan perspective. However, if we wish to construct the links between school and life very clearly and specifically, we have to reconsider our definition of curriculum. If we want individuals to construct a praxis and maintain a dignified stance throughout their lives, we have to imagine the individual and curriculum as a whole. When such a definition of curriculum is put forward, the individual will naturally comprehend the importance of lifelong learning and will be able to deal with the problems that come with change. What definition of curriculum do we need in order to address curriculum in unity with the child instead of as a separate structure from the child?

In this context, Pinar's definition of curriculum (2004, pp. 186-187) is significant: "Provocation for students to reflect on and to think critically about themselves and the world they will inherit". Only if individuals engage in critical self-reflection about the environment and the world they live in can they develop a praxis toward environmental and global problems. Because the nature of the relationship between the teacher and the student is very complex, reaching such a goal takes effort. If teachers perceive the curriculum more like a journey taken with, experienced with, and accompanied by the student, rather than a collection of predefined learning outcomes, they will regard students' status nonhierarchically. Over time, this journey will help the student discover their inner world, develop a critical perspective, gain an awareness of their self-existence, and construct a holistic view of nature and the world.

Paul Klohr, in 1974, was first to express the notion of constructing a holistic and organic view of curriculum (Pinar et al. 1995). All humane activities, he maintained, are essentially holistic in nature. In other words, all humane activities, including knowledge production, are linked with and related to each other. For this reason, all of humanity's problems must be addressed from a deep and wide perspective (Horn 2007). Learning is a dialectical process; it is through a critical perspective that we learn deeper and wider. Thus, we must address the Covid-19 pandemic not only as a problem within the scope of medical science but also from economic, social, political, ecological, and philosophical perspectives, questioning its whys and wherefores and developing a network of its relationships with various domains of life, Only then can we attain a thorough comprehension of it.

The first step toward developing a holistic and organic view of nature and self is caring about living beings and social life beyond one's own. Noddings (1995) emphasizes that using care-based themes more often in school curricula is very beneficial to students and provides them with a comprehensive intellectual basis for thinking about existential problems, respecting the rights of living beings other than humans, obtaining critical intellectual competency, and widening their cultural horizons.

While gaining these abilities during the journey taken with the teacher, the individual will also discover the nature of passion, a unique feeling that gives meaning to everything we do in life. It cannot be denied that behind technological and scientific progress are imagination and passion. Passion is not something that can be learned from course books. It can be awakened only through the conversation between the student and the teacher. Pinar (2004, p. 248) highlights the point of this conversation as follows: 
The educational point of the curriculum is to draw students out of themselves into unknown (to them) terrains of the "cultural field", enabling them to engage the world with passion and competence while never breaking the bridges of psychic attachment that makes the process of education subjectively meaningful.

Charles Silberman's "killers of the dream" in Crisis in the Classroom (1970, p. 10) is an overview of our schools today. Expecting school and curriculum to develop the workforce of the nation, enhance new generations with knowledge and skills in science and technology, and contribute to the future of the country are goals almost anyone would agree with. However, it cannot be acceptable for schools to ignore individuals and their needs in favor of society, technology, and global economic competition. Instead of functioning as killers of the dream, we should defend the role of school and curriculum as students' companions on their intellectual journeys of discovery.

Art and literature are important means to obtaining a holistic and organic mindset. Although efforts have been made to ensure that art has an important place in curricula, concepts such as economic competition and technological superiority are always emphasized more. Maxine Green's emphasis, in her work, Art and Imagination: Reclaiming the Sense of Possibility, is very meaningful in this sense:

The danger afflicting both teachers and students because of such emphases is, in part, the danger of feeling locked in to existing circumstances defined by others. Young people find themselves described as "human resources" rather than as persons who are centers of choice and evaluation. It is suggested that young people are to be molded in the service of technology and the market, no matter who they are. (Greene 1995, p. 379)

Among the foundational values of a new curriculum, I argue that the following are fundamental:

- An innocent and rational human-environment relationship;

- An emphasis on humane values, such as an individual's uniqueness, and a democratic social life;

- Acceptance of the fact that the individual is the main actor in knowledge construction, cultural production, and their exchange;

- Awareness that a high-level consciousness plays an important role in human creativity, knowledge, and culture.

Today, in an education system based on assessment and standardized tests, the basic needs of students are to reflect upon their inner life, enrich their imagination, and develop a comprehension of the social structures they and others throughout the world mutually inhabit.

In this context, what process should we follow in order to have a provocative conversation, and which dimensions should be included in this process? In Reflective Teaching: Professional Artistry Through Inquiry, Henderson (2001) presents us with a conceptual framework for putting a holistic and provocative conversation into practice. The structure that he proposes and has named $3 \mathrm{~S}$ consists of subject matter, self-learning, and social learning.

Subject matter refers not to a conventional course of study but to problem areas that can be used to teach about democratic life and culture, develop individual thinking skills, and enable the individual to put forward their own unique performance. At this stage, 
Henderson emphasizes peer learning, cooperative research, project-based studies, authentic problems, real-world experience, and critical and creative thinking.

The second stage, self-learning, focuses on the individual, highlighting healthy self-perception, values skills such as lifelong learning, active participation in democratic society, and taking an active role in class and school management. Based on the principle that an individual's interests and thoughts are inherently valuable, self-learning is premised on the acceptance of everyone's uniqueness and regards the individual's interests and thoughts as inherently valuable.

The third $S$ refers to society. At this stage, equality, difference, and civility are at the forefront. Equity is about people not being superior to each other and having equal civil rights with each other. It also refers to considering all individuals equal in educational settings. Diversity refers to differences in people's views and lifestyles as a sign of societal richness. Civility refers to democracy. It includes respect for the opinions of others and democratic attitudes.

In all activities and studies, an education system should accept these three values as foundational and students should be encouraged to internalize them. This kind of curriculum structure will abolish the gap between school and life, provide students with the activities they need to actively participate in a democratic society. Anything that has significance in child's life can be part of the curriculum. Such a school would be prepared for a pandemic like Covid-19 before its emergence. For example, children could research, from an interdisciplinary perspective, pandemics that have severely affected human history. They could investigate the pandemic problem in a broad range of subject areas, from history to economics, art to mathematics, geography to medical science. This way, children naturally acquire valuable knowledge about pandemics - from their economic consequences to how to protect their own health. This learning process can also be subject to many performative studies. For example, students can take an active part in running the cafeteria, library, classes, and school, thereby gaining a variety of valuable skills, such as teamwork, thoroughness, and work discipline.

Here, a question arises: How will measurement and evaluation occur in this kind of learning process? In minds shaped and occupied by the Tyler rationale, the one thing that never ceases is the centering of measurement and evaluation. In the curricular perspective that I propose, evaluation does take place, but it is not Tylerian. In her study, Deliberative Conversation: Consciousness-Raising for Democratic Interdependence, Bilek-Golias (2015) adopts an assessment and evaluation perspective containing five principles, inspired by Rutledge's (2012) The Case for General Education. The five principles-lightness, quickness, exactitude, visibility, and multiplicity—can also be regarded as guiding principles in curriculum development. For instance, multiplicity requires the individual to question what it means to be a member of a democratic society. This questioning leads to their comprehending the responsibilities of such membership and provides continuous guidance in the co-development of curriculum during the instructional process.

\section{Conclusion: What we have learned from Covid-19}

Covid-19 captured the world in a very short time and became not only a health crisis but also a global economic, social, and educational crisis. Countries across the world have fought against it with extraordinary measures, among which the shutdown of schools is one of the most significant. Over 1.5 billion students worldwide stayed away from their 
schools. Educational systems faced an intense learning crisis, unlike any they had experienced before.

What have we learned from this crisis? What kind of reality does it force us to confront? Thanks to the pandemic, issues that have deeply affected our lives but have been kept out of our agendas have come to the fore. As a result of this crisis, not only have we started to rediscuss curriculum, but other issues, including the technical capacities of schools, the wellness of teachers, and the continuation of learning under various circumstances have taken a well-deserved seat at the table.

The first thing we learned from this crisis was the significance of our relationship with nature. We began to rethink our relationship to animals, oceans, and forests. We saw nature start to refresh itself, as the earth began to repair the destruction caused by the unbalanced and unreasonable acts of humanity. This is undoubtedly a significant learning outcome in terms of the curriculum. Undoubtedly, a more ecology and environment-centered curriculum will play a significant role in the future. To that end, schools should prepare comprehensive action plans to nurture students' love of animals and nature. Awareness of the earth as humanity's one and only home should constitute the soul of the curriculum.

The continuation of learning emerged as a priority during the pandemic since children's connection to their schools needed to be maintained. Technology came along as a savior. From kindergarten to higher education, schools offered web-based and online classes, both synchronous and asynchronous. In classes delivered through distance education, students have had to cultivate the qualities of self-control, self-regulation, and work discipline.

Even though schools' use of technology is a compelling feature of the pandemic, it is not possible to achieve thorough learning only by listening or watching content. We have to think about how schools can self-manage learning processes without depending solely on technology. Instead of championing technologies that simply provide students with audible and video content through devices - technologies in which pedagogy is irrelevantschools should invest in technologies that help students become lifelong learners, enrich their learning processes, and focus on critical self-reflection, problem-solving skills, imagination, ideas, and projects involving social problems.

The pandemic has also underlined class differences within and between societies. Millions of children have missed online classes because they lack access to the internet. Where poverty was already a big disadvantage in the physical school environment, the pandemic has doubled its effect. Despite the neo-liberal discourses, the necessity of states to increase their investment in public education in favor of the poor should be a primary focus of curriculum theory.

We have also learned that our schools are deficient in imparting careful, common-sense action and the knowledge of how students can protect their health. Every day, children have had to hear news of infected family members or confront the numbers of dead due to Covid-19 on TV or the internet. In addition, expressions of extreme individualism-a reflection of competitive education practices that are not rooted in democratic consciousness-occurred during this pandemic, further threatening society. Thoughtless travel by infected individuals to places outside their quarantine areas had an enormous effect on the spread of Covid-19. Questions such as what is a pandemic, what are its effects on families and countries, and what do these effects mean might have been answered by building a democratic consciousness through effective health literacy. Unfortunately, we did not devote the time and resources to health literacy that we devoted to financial and technological literacy. I expect that we will be talking equally about them both in the future. 
Lastly, I believe that the educational effects of the pandemic will differ vastly around the world. While the curricular reflexes will be stronger in countries with high income levels and democratic social structures, I anticipate that these reflexes will be weaker and will disappear over time in countries with lower income levels, education systems based on competition, and dysfunctional meritocracies. On the other hand, thinking of curriculum as some magical power in itself will not work since it is, in reality, a textual mirror that reflects the socio-political, philosophical, and cultural codes of the society in which it is embedded. I conclude that curricular reactions against this pandemic will take place in parallel with changes in the socio-cultural and political structures.

\section{References}

Arnold, H. E., Cohen, F. G., \& Warner, A. (2009). Youth and environmental action: Perspectives of young environmental leaders on their formative influences. The Journal of Environmental Education, 40(3), 27-36.

Bajd, B., \& Leščanec, T. (2011). The influence of the eco-school and healthy school projects on environmentally responsible behavior of primary school pupils. Education and Health Care, 21, 79-85.

Baker, B. (2019). Echo, eco, techno: Curriculum studies' contributions to past-present-future imaginings. Keynote, 7th International Congress on Curriculum and Instruction (ICCI), Ankara. 9-11 October.

Beck, U. (1992). Risk society: Towards a new modernity (M. Ritter, Trans.). London: Sage Publications.

Bernstein, M. A. (1987). The Great Depression: Delayed recovery and economic change in America, 19291939. Cambridge: Cambridge University Press.

Bilek-Golias, B. (2015). Deliberative conversation: Consciousness-raising for democratic interdependence. In J. G. Henderson (Ed.), Reconceptualizing curriculum development: Inspiring and informing action (pp. 110-121). New York, NY: Routledge.

Blythe, C., \& Harré, N. (2012). Inspiring youth sustainability leadership: Six elements of a transformative youth eco-retreat. Ecopsychology, 4(4), 336-344.

Bobbitt, J. F. (1918). The curriculum. Boston, MA: Houghton Mifflin.

Callahan, R. E. (1964). Education and the cult of efficiency: A study of the social forces that have shaped the administration of the public schools. Chicago, IL: University of Chicago Press.

Callinicos, A. (2020, February 18). Coronavirus shows capitalism is sick. Socialist Worker. https://socia listworker.co.uk/art/49631/Coronavirus+shows+capitalism+is+sick

Carrington, D. (2019, March 19). School climate strikes: 1.4 million people took part, say campaigners. The Guardian. https://www.theguardian.com/environment/2019/mar/19/school-climate-strikes-more-than1-million-took-part-say-campaigners-greta-thunberg

Cheng-Man Lau, D. (2001). Analyzing the curriculum development process: Three models. Pedagogy, Culture, and Society, 9(1), 29-44.

Counts, G. S. (1932). Dare the school build new social order. New York, NY: The John Day Company.

Cremin, L. A. (1988). American education: The metropolitan experience, 1876-1980. New York, NY: Harper \& Row.

Dewey, J. (1897). My pedagogic creed. New York, NY: E. L. Kellog \& Co.

Eco-Schools (2020a). About eco-schools. https://www.ecoschools.global/how-does-it-work.

Eco-Schools (2020b). Ten topics. https://www.eco-schools.org.uk/secondary-pathway/ten-topics/

Elder, G. H. (1999). Children of the Great Depression: Social change in life experience. Boulder, CO: Westview Press.

Gadotti, M. (2010). Reorienting education practices towards sustainability. Journal of Education for Sustainable Development, 4(2), 203-211.

Goals 2000: Educate America Act (1994). https://uscode.house.gov/view.xhtml?path=\&req=granu leid\%3AUSC-prelim-title20-section5812\&f=\&fq=\&num=0\&hl=false\&edition=prelim

Greene, M. (1995). Art and imagination: Reclaiming the sense of possibility. Phi Delta Kappan, 76(5), $378-382$.

Gutek, L. G. (1984). George S. Counts and American civilization: The educator as social theorist. Macon, GA: Mercer University Press.

Gutek, L. G. (1988). Philosophical and ideological perspectives on education. Upper Saddle River, NJ: Prentice Hall. 
Henderson, J. G. (2001). Reflective teaching: Professional artistry through inquiry. Upper Saddle River, NJ: Prentice Hall.

Hickman, G., Riemer, M., \& YLEC Collaborative (2016). A theory of engagement for fostering collective action in youth leading environmental change. Ecopsychology, 8(3), 167-173.

Horn, R. A. Jr. (2007). Foundations of reconceptualized teaching and learning. In J. L. Kincheloe \& R. A. Horn Jr. (Eds.), The Praeger handbook of education and psychology (pp. 439-448). Westport, CT: Praeger Publishers.

Jackson, P. (1992). Conceptions of curriculum and curriculum specialists. In P. Jackson (Ed.), Handbook of research on curriculum (pp. 3-40). New York, NY: Macmillan.

Judd, H. C. (1918). Introduction to the scientific study of education. Boston, MA: Ginn \& Company.

Kliebard, H. M. (2004). The struggle for the American curriculum: 1893-1958. New York, NY: Routledge Falmer.

Krnel, D., \& Naglič, S. (2009). Environmental literacy comparison between eco-schools and ordinary schools in Slovenia. Science Education International, 20(1/2), 5-24.

Lagemann, E. C. (1992). Prophecy or profession? George S. Counts and the social study of education. American Journal of Education, 100(2), 137-165.

Lawton, D. (2009). What knowledge is of most worth? An old question revisited in England. In R. Cowen \& A. Kazamias (Eds.), International handbook of comparative education (pp. 813-821). New York, NY: Springer.

Leinfelder, R. (2013). Assuming responsibility for the Anthropocene: Challenges and opportunities in education. In H. Trischler (Ed.), Anthropocene: Exploring the future of the age of humans (vol. 3, pp. 9-28). Munich: Rachel Carson Center Perspectives. http://www.environmentandsociety.org/ sites/default/files/1303_anthro_web.pdf

Mair, S. (2020, March 30). What will the world be like after coronavirus? Four possible futures. The Conversation. https://theconversation.com/what-will-the-world-be-like-after-coronavirus-fourpossible-futures-134085

Martin, E. (2020, April 14). 'This crisis is like no other': Coronavirus recession will likely be worst since the Great Depression, predicts IMF. Fortune. https://fortune.com/2020/04/14/coronaviru s-recession-predictions-great-depression-covid-19-lockdown-crisis-imf/

Marx, K. \& Engels, F. (1910). Manifesto of the Communist party. Chicago, IL: Charles H. Kerr Company.

Meadway, J. (2020, March 25). Coronavirus is the greatest challenge capitalism has ever faced: Will a new system result? NewStatesman. https://www.newstatesman.com/politics/economy/2020/03/ coronavirus-financial-economy-impact-labour-market

Mogensen, F. \& Mayer, M. (2005). ECO-school trends and divergences: A comparative study on ECOschool development processes in 13 countries. Vienna: Austrian Federal Ministry of Education, Science and Culture. https://www.ensi.org/global/downloads/Publications/173/ComparativeStud y1.pdf.

National Commission on Excellence in Education (1983). A nation at risk: The imperative for educational reform. The Elementary School Journal, 84(2), 112-130.

Noddings, N. (1995). Teaching themes of care. Phi Delta Kappan, 76(9), 675-679.

OECD (2020a). Evaluating the initial impact of COVID-19 containment measures on economic activity. Paris: OECD. https://read.oecd-ilibrary.org/view/?ref=126_126496-evgsi2gmqj\&title=Evaluating _the_initial_impact_of_COVID-\%2019_containment_measures_on_economic_activity

OECD (2020b). A framework to guide an education response to the COVID-19 pandemic of 2020. Paris: OECD. https://read.oecd-ilibrary.org/view/?ref=126_126988-t631xosohs\&title=A-framework-toguide-an-education-response-to-the-Covid-19-Pandemic-of-2020

Pauw, J. B. D., \& Petegem, P. V. (2013). The effect of eco-schools on children's environmental values and behaviour. Journal of Biological Education, 47(2), 96-103.

Pinar, W. F., Reynolds, W. M., Slattery, P., \& Taubman, P. (1995). Understanding curriculum: An introduction to historical and contemporary curriculum discourses. New York, NY: Peter Lang.

Pinar, W. F. (2004). What is curriculum theory. Mahwah, NJ: Lawrence Erlbaum.

Rutledge, S.A. (2012, November 8). The case for general education. DesignIntelligence. https://www. di.net/articles/the-case-for-general-education/

Scott, W. (2009). Judging the effectiveness of a sustainable school: A brief exploration of issues. Journal of Education for Sustainable Development, 3(1), 33-39.

Silberman, E. C. (1970). Crisis in the classroom: The remaking of American education. New York, NY: Random House.

Spencer, H. (1895). Education: Intellectual, moral, and physical. New York, NY: D. Appleton \& Co. 
Steeves, K. A., Bernhardt, P. E., Burns, J. P., \& Lombard, M. K. (2009). Transforming American educational identity after Sputnik. American Educational History Journal, 36(1), 71-87.

Steffen, W., Grinevald, J., Crutzen, P., \& McNeill, J. (2011). The Anthropocene: Conceptual and historical perspectives. Philosophical Transactions of the Royal Society A: Mathematical, Physical and Engineering Sciences, 369(1938), 842-867.

Sumner, A. Hoy, C. \& Ortiz-Juarez, E. (2020). Estimates of the impact of Covid-19 on global poverty. Helsinki: United Nations University World Institute for Development Economics Research (UNUWIDER). https://www.wider.unu.edu/publication/estimates-impact-covid-19-global-poverty

Taylor, J. (2020, March 14). Coronavirus and the NBN: Will your broadband be up to speed if you have to work from home? The Guardian. https://www.theguardian.com/technology/2020/mar/13/coronaviru s-and-the-nbn-will-your-broadband-be-up-to-speed-if-you-have-to-work-from-home.

Taylor, W. F. (1913). The principles of scientific management. New York, NY: Harper \& Brothers Publishers.

Thorndike, E. L. (1918). The nature, purposes, and general methods of measurements of educational products. In G. M. Whipple (Ed.), The seventeenth yearbook of the National Society for the Study of Education. Part II: The measurement of educational products. Bloomington, IL: Public School Publishing.

Tyler, R. W. (1949). Basic principles of curriculum and instruction. Chicago, IL: University of Chicago Press.

UNESCO (2020a). COVID-19 educational disruption and response. Paris: UNESCO. https://en.unesco.org/ covid19/educationresponse

UNESCO (2020b). Distance learning solutions. Paris: UNESCO. https://en.unesco.org/covid19/educationr esponse/solutions.

United Nations (2020). Policy brief: The impact of COVID-19 on children. New York, NY: United Nations. https://www.un.org/sites/un2.un.org/files/policy_brief_on_covid_impact_on_children_16_april_2020. pdf.

Urban, W. J. (2010). More than science and Sputnik: The National Defense Education Act of 1958. Tuscaloosa, AL: University of Alabama Press.

Wals, A. E. J., \& Corcoran, P. B. (2012). Re-orienting, re-connecting and re-imagining: Learning-based responses to the challenge of (un)sustainability. In A. E. J. Wals \& P. B. Corcoran (Eds.), Learning for sustainability in times of accelerating change (pp. 21-32). Wageningen: Wageningen Academic Publishers.

WHO [World Health Organization] (2020). Mental health and psychosocial considerations during the COVID-19 outbreak. Geneva: WHO. https://www.who.int/docs/default-source/coronaviruse/menta 1-health-considerations.pdf?sfvrsn=6d3578af_8\&ua=1.

Woolley, S., Sattiraju, N. \& Moritz, S. (2020, March 26). US schools trying to teach online highlight a digital divide. Bloomberg. https://www.bloomberg.com/news/articles/2020-03-26/covid-19-school-closu res-reveal-disparity-in-access-to-internet.

World Economic Forum (2017). Global shapers survey: Annual survey 2017. Geneva: World Economic Forum. http://www.shaperssurvey2017.org/static/data/WEF_GSC_Annual_Survey_2017.pdf.

Zalasiewicz, J., Williams, M., Steffen, W., \& Crutzen, P. (2010). The new world of the Anthropocene. Environmental Science \& Technology, 44(7), 2228-2231.

Publisher's Note Springer Nature remains neutral with regard to jurisdictional claims in published maps and institutional affiliations.

Sümer Aktan is an Associate Professor in the Necatibey Faculty of Education at Balikesir University, Turkey. He is primarily interested in curriculum theory and curriculum history. Dr. Aktan investigates how curriculum theory shapes and is shaped by culture, technology, and ideology. Before his university career, he worked as a primary school teacher in the Balikesir province. 